\title{
THE EFFECT OF THE INGESTION OF FOOD- STUFFS ON THE RESPIRATORY EXCHANGE IN PULMONARY TUBERCULOSIS *
}

\author{
WILLIAM S. MCCANN, M.D.
}

With the technical assistance of G. F. Soderstrom

NEW YORK

Elaborate studies of the effect of foodstuffs on the respiratory metabolism have been made by Rubner ${ }^{1}$ and Lusk, ${ }^{2}$ who are the principal workers in this field. Reference should be made to the latter for an excellent review of the subject. These investigations were concerned chiefly with the calorimetric observations, in which the magnitude of pulmonary ventilation was not measured.

In a previous communication ${ }^{3}$ the effect of protein ingestion on the heat production of two tuberculous patients and two normal subjects was found to be identical. On a priori grounds the assumption was made that the pulmonary ventilation varies directly with the metabolism. Confirmatory evidence on this point is given by Peabody ${ }^{4}$ who shows the parallelism between the minute volume of air expired and the level of metabolism in patients with exophthalmic goiter. The general validity of the assumption is well demonstrated by Pearce, ${ }^{5}$ who showed that total ventilation and cardiac volume output, within the capacity of the organism, vary directly with the rate of oxygen consumption.

Since the problem of selecting a proper diet for patients with pulmonary tuberculosis involves a knowledge of the effect of food ingestion on the function of the diseased lungs, it seems important to present the data of a few experiments bearing on this point.

Technic.-The apparatus used for this work was a Tissot spirometer. This spirometer has a capacity of eighty-four liters. The bell is counterpoised by a container into which water siphons, so that as the buoyancy of the bell diminishes the weight of the counterpoise increases by an equivalent amount. A description of this device is to be found in the monograph by Carpenter. ${ }^{\sigma}$

\footnotetext{
* From the Russell Sage Institute of Pathology in affiliation with the Second Medical Division of Bellevue Hospital.

1. Rubner, M.: Die Gesetze des Energie-verbrauchs bei der Ernährung, 1902.

2. Lusk, G.: Science of Nutrition, Ed. 3, 1917, pp. 223-247.

3. McCann, W. S., and Barr, D. P.: Clinical Calorimetry, Paper No. 29, The Metabolism in Tuberculosis, Arch. Int. Med. 26:663 (Nov.) 1920.

4. Peabody, F.: Respiration in Disease, Oxford Medicine, 1:409.

5. Pearce, R. G.: The Cardiorespiratory Mechanism in Health and Disease, Arch. Int. Med. 27:139 (Jan.) 1921.

6. Carpenter, T. M.: A Comparison of the Methods for the Study of the Respiratory Exchange, Carnegie Inst. of Washington, D. C., Pub. No. 216.
} 
The wire connecting the spirometer bell and the counterpoise runs over a pulley 12 inches in diameter. On this pulley are graduation marks for each liter. Readings are made to the first place of decimals. These calibrations were made with a Bohr meter at $23 \mathrm{C}$. Since calculations were to be based on dry gas volume, it was necessary to apply calibration corrections. These corrections were made as follows: A metal bomb containing dry oxygen was weighed. The gas was then allowed to escape, passing through water into the spirometer. At intervals of five liters on the spirometer scale the bomb was closed and again weighed. The difference in weight equals the weight of oxygen admitted to the spirometer. The temperature of the spirometer and the barometer reading were noted. .The observed reading of the gas volume in the spirometer was then corrected for aqueous vapor tension at the observed temperature, to $0 \mathrm{C}$. and $760 \mathrm{~mm}$. dry. This dry gas volume was then compared with the volume which the known weight of dry oxygen gas would occupy at $0 \mathrm{C}$. and $760 \mathrm{~mm}$. dry. This is obtained by multiplying the weight of oxygen by $22.4 / 32$. In this way a calibration curve was constructed. The oxygen used contained about 0.4 per cent. chiefly argon.

The valve used to separate inspired and expired air was made by G. F. Soderstrom. A sketch of this valve is shown in the accompanying figure. After having devised the valve it was found that a similar valve had been described by Tigerstedt. ${ }^{7}$ The mouthpiece used was identical with that of the American gas masks. ${ }^{8}$ The nose was then closed with a spring clip.

Patients were prepared in the usual manner for basal metabolism determinations. No food was allowed after 4:30 or $5 \mathrm{p} . \mathrm{m}$. on the preceding day so that the basal determinations were generally made at least sixteen hours after eating. A period of absolute rest of twenty minutes or more before the test was observed in all bed patients and thirty minutes at least of absolute rest reclining in a steamer chair for all normal subjects or ambulatory patients.

Many persons on the first occasion of breathing through the mouth, with the nose closed by a clip, will alter their breathing from the normal type. The invariable tendency is to over ventilate either by increasing the depth of breathing, or by increasing the rate. Some patients can never be trained not to do this. In the experiments given here subjects were allowed to become accustomed to the apparatus before the beginning of the experiment. The rate of respiration was counted before

7. Tigerstedt, R.: Lehrbuch der Physiologie des Menschen, Leipzig, 1:89, 1902. The valve is ascribed to Lovén, but the original reference is not given.

8. This was obtained from the Siola Rubber Manufacturing Co., 103 Park Ave., New York. 
inserting the mouthpiece and the normal type of breathing was closely observed. After adjusting the mouthpiece and nose clip the respirations were again observed until they again became of normal rate and type. At this time 8 or 10 liters of expired air were admitted into the spirometer in order to get the approximate minute volume and to fill the dead space of the apparatus with air of the same composition as that to be measured and analyzed. This gas was expelled as completely as possible, i.e. to zero mark. If the subject continued to breathe normally, the three-way valve opening into the spirometer was thrown open at the end of an expiration and the time noted. After from six to ten minutes, depending on the.minute volume expired, the valve was closed at the end of expiration and the time noted.
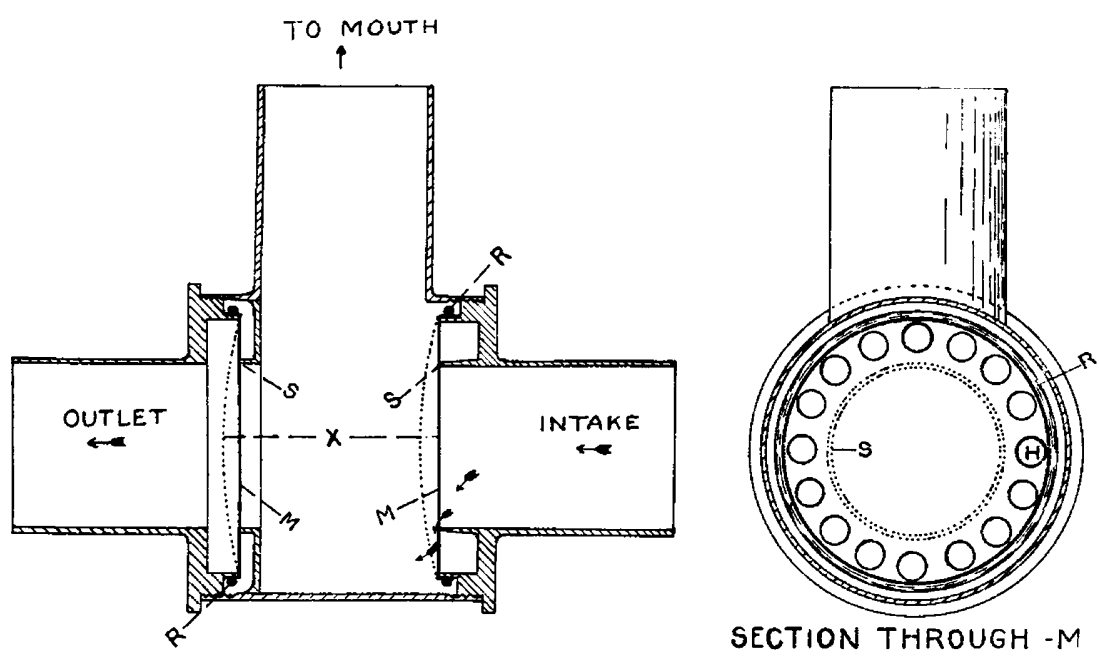

Modified Lovén valve. $M$ and $M^{\prime}$ are very thin rubber membrane, which 11 the closed position is in contact with the rims $S$ of the valve seats. The membranes are held in place by the rings $R$, which slip on and off. The holes in the membrane $\mathrm{H}$, are burned through the rubber after it is fastened in place. Contact of $M$ with $S$ is made more secure by moistening the membrane with glycerin. $\mathrm{X}$ shows the open position of membranes, which open and close reciprocally.

Movement on the part of the patient, distress from tickling sensations in throat or a desire to cough were made matters of note. The manner of closure of the lips over the mouthpiece was carefully watched. If there was any doubt as to the possibility of leaks about the lips or nostrils a lather of shaving soap was applied. A leak would be detected by the formation of a bubble.

It will be seen, therefore, that the valve which was used required considerable care. For this study it was preferred to the other forms in use because of its small dead space, the ease with which it opened 


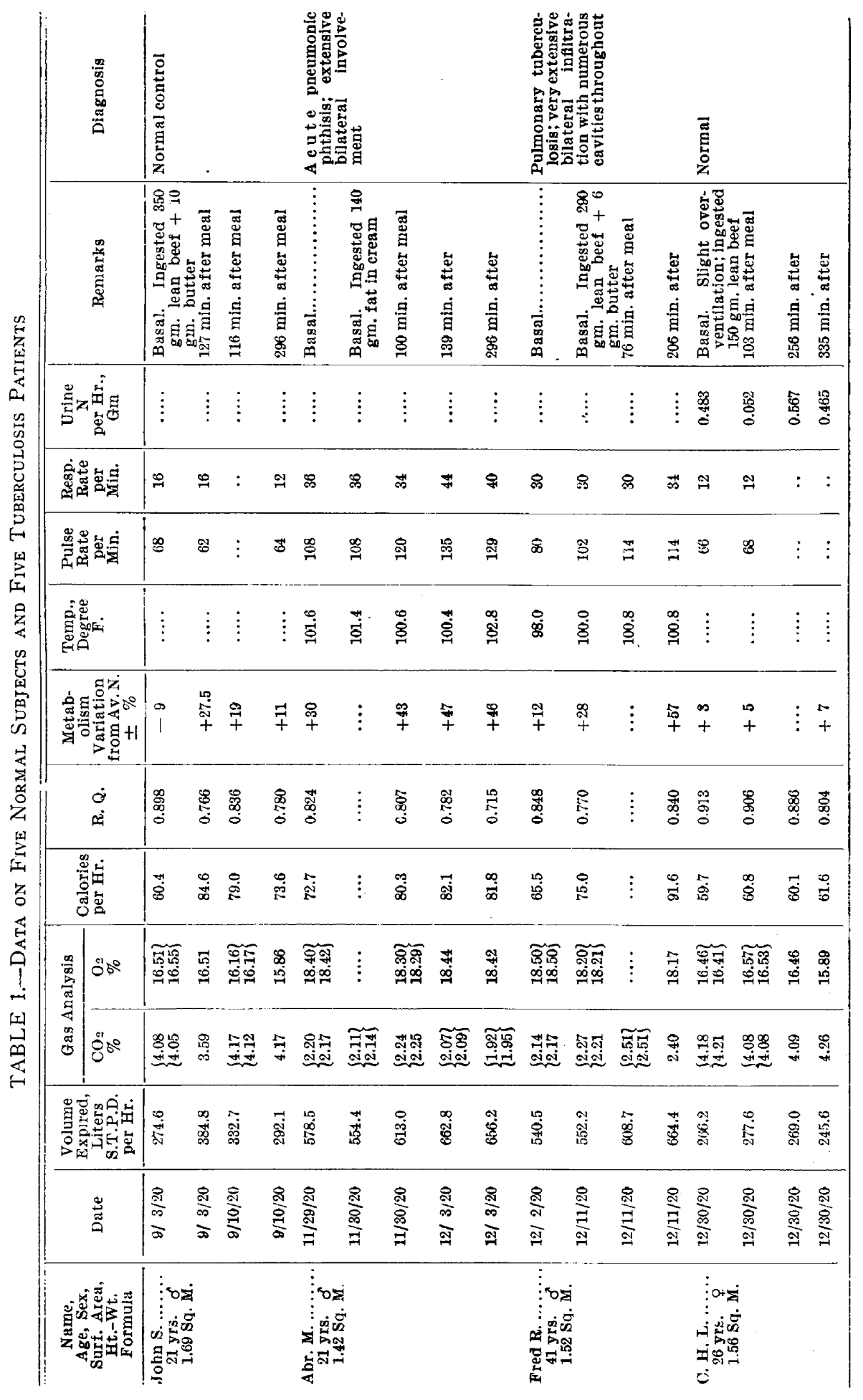




\begin{tabular}{|c|c|c|c|c|c|c|c|c|c|c|c|c|c|c|c|c|c|c|}
\hline 骂 & & 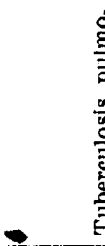 & 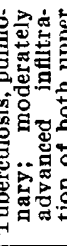 & 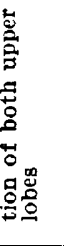 & & & 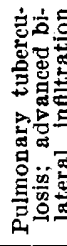 & 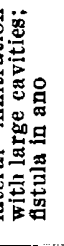 & & 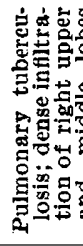 & & 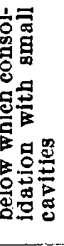 & $\begin{array}{l}\overline{0} \\
\text { : } \\
0\end{array}$ & & 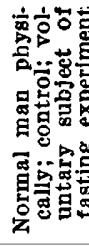 & & & \\
\hline 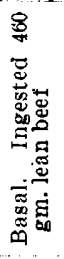 & 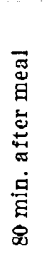 & 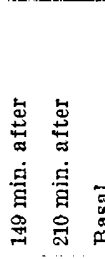 & 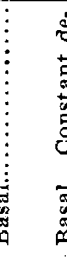 & 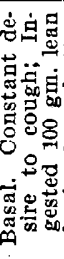 & 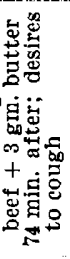 & 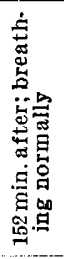 & 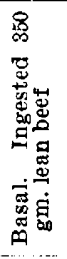 & 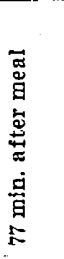 & 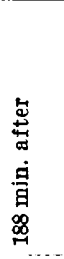 & 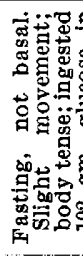 & & 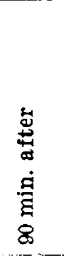 & 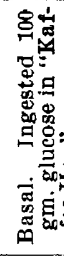 & 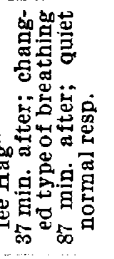 & 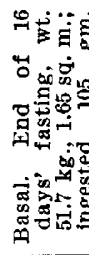 & 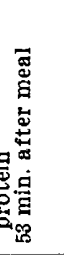 & 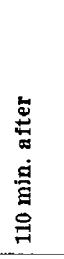 & 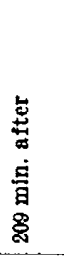 \\
\hline 票 & 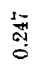 & 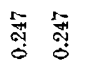 & $\vdots$ & $\vdots$ & $\vdots$ & $\vdots$ & $\vdots$ & $\vdots$ & $\vdots$ & $\vdots$ & $\vdots$ & $\vdots$ & $\vdots$ & $\vdots \vdots$ & 兽 & 呇 & 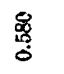 & 番 \\
\hline$\stackrel{⿻}{*}$ & $\approx$ & 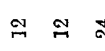 & N & E & I & $\nexists$ & $\stackrel{9}{\oplus}$ & జิ & $\stackrel{\mathscr{N}}{\mathrm{N}}$ & 9 & $\vec{a}$ & $\stackrel{\oplus}{\sim}$ & $s$ & $\Phi \infty$ & $\infty$ & $\infty$ & $\alpha$ & $\infty$ \\
\hline 8 & 8 & 88 & $\mathbb{N}$ & న & in & న & $p$ & $\infty$ & $\$$ & $\varnothing$ & $\stackrel{\circ}{\circ}$ & $\stackrel{g}{g}$ & $R$ & $8 \%$ & \$ & $\vdots$ & 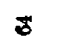 & 8 \\
\hline$\vdots$ & $\vdots$ & $\vdots \vdots \vdots$ & $\xi$ & : & $\begin{array}{l}\infty \\
\stackrel{9}{\circ}\end{array}$ & 苛 & $\stackrel{\infty}{\infty}$ & $\ddot{8}$ & $\ddot{8}$ & $\stackrel{\infty}{8}$ & 芦 & 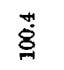 & $\stackrel{\infty}{5}$ & $\vdots \vdots \vdots$ & 용 & $\vdots$ & $\vdots$ & $\stackrel{\$}{\infty}$ \\
\hline$\circ$ & + & $\overrightarrow{7} \overrightarrow{7}+$ & + & 0 & $i$ & $\stackrel{\infty}{1}$ & $\begin{array}{l}c \\
+\end{array}$ & 啼 & 茄 & $\stackrel{8}{+}$ & $\vdots$ & $\vdots$ & $\bar{T}$ & 00 & ิิ & $\overrightarrow{1}$ & 蚂 & 苛 \\
\hline 芯 & 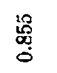 & $\begin{array}{cc}0 \\
\substack{0 \\
0 \\
0} \\
0\end{array}$ & 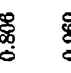 & 恋 & ฐี & 要 & $\begin{array}{l}0 \\
0 \\
0 \\
0\end{array}$ & 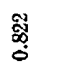 & $\begin{array}{l}\tilde{8} \\
\text { on } \\
0\end{array}$ & $\begin{array}{l}\stackrel{0}{0} \\
\stackrel{0}{0} \\
0\end{array}$ & 兽 & ஜ & 胥 & 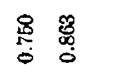 & 总 & $\begin{array}{l}\text { 䒿 } \\
\stackrel{0}{0}\end{array}$ & $\begin{array}{l}\stackrel{8}{8} \\
\stackrel{8}{0}\end{array}$ & $\begin{array}{l}\text { 藍 } \\
\end{array}$ \\
\hline 옹 & 옹 & $\stackrel{0}{\infty} \ddot{8}$ & : & : & 总 & 曷 & $\begin{array}{l}0 \\
\stackrel{0}{0}\end{array}$ & $\frac{8}{\infty}$ & $\stackrel{0}{\dot{\infty}}$ & 趈 & 承 & $\stackrel{m}{*}$ & $\stackrel{m}{\square}$ & 管 & $\stackrel{20}{q}$ & व̊ㅇㅇ & : & 옿 \\
\hline 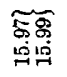 & $\stackrel{\overrightarrow{0}}{\stackrel{\oplus}{0}}$ & 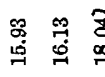 & 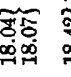 & ד্ণ & 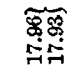 & 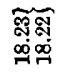 & 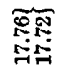 & 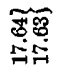 & 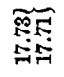 & 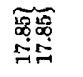 & 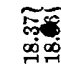 & 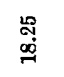 & 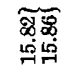 & 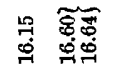 & 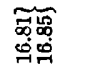 & 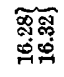 & 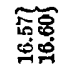 & 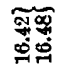 \\
\hline 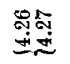 & $\underset{\dddot{q}}{\dddot{*}}$ & 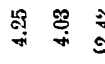 & 쿼월 & 承尔 & 象学 & 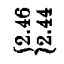 & 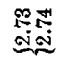 & 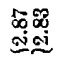 & 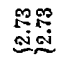 & 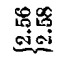 & 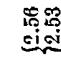 & $\stackrel{8}{g}$ & 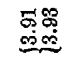 & 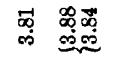 & 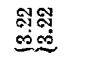 & 禺? & 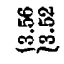 & 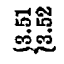 \\
\hline స్ํำ & 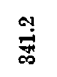 & 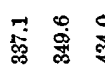 & 泉 & 离 & $\stackrel{\circ}{\stackrel{\oplus}{\circ}}$ & $\stackrel{\circ}{\rightarrow}$ & 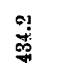 & 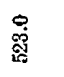 & 哭 & 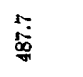 & 菅 & $\begin{array}{l}\text { 电 } \\
\text { 兽 }\end{array}$ & $\begin{array}{l}\infty \\
0 \\
:\end{array}$ & 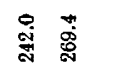 & 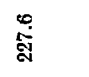 & 趂 & 范 & 芦 \\
\hline$\frac{\stackrel{8}{7}}{\stackrel{9}{9}}$ & 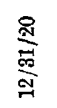 & 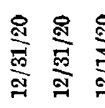 & 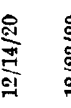 & 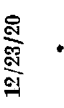 & • & 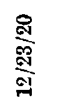 & 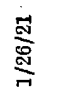 & $\frac{\frac{a}{a}}{\frac{a}{\infty}}$ & $\frac{a}{\frac{a}{\infty}}$ & 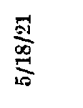 & 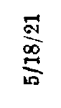 & $\stackrel{\vec{g}}{\stackrel{\vec{g}}{00}}$ & 预 & 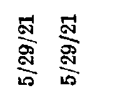 & $\underset{7}{\stackrel{9}{3}}$ & 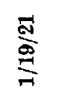 & $\stackrel{\sqrt{3}}{\stackrel{\vec{g}}{\sigma}}$ & 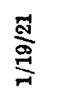 \\
\hline 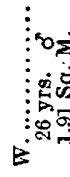 & & & 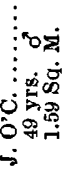 & & & & 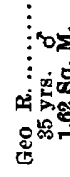 & & & 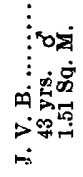 & & & 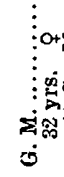 & & 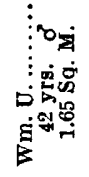 & & & \\
\hline
\end{tabular}


(pressure of from 1 to $2 \mathrm{~mm}$. water) and the complete lack of leakage back. The absence of these virtues might have made considerable difference in the volume of air respired.

Samples of air from the spirometer were drawn into special sampling. bottles ${ }^{9}$ over a solution consisting of equal parts of glycerin and saturated sodium chlorid solution. The sample of air can be kept unchanged for at least twenty-four hours over this solution. ${ }^{10}$ In our hands this has been fully as satisfactory as mercury and much cheaper.

The air analyses were made with a modification of Henderson's ${ }^{11}$ air analyser. In its original form the apparatus had a very short water jacket. In our apparatus a long water jacket was used and in place of the original absorber shell for carbon dioxid absorption a bulb was used very much as in the Haldane apparatus. These are minor details. The essential feature of the apparatus is the very ingenious four-way stopcock of Henderson.

Gas burets were recalibrated with mercury and calibrations and technic were checked by analyses of pure outside air. The values obtained for carbon dioxid vary from 0.02 to 0.03 per cent. and for oxygen from 20.93 to 20.97 per cent. In calculation Haldane's value for oxygen in outside air was used: 20.93 per cent. In analyses of expired air duplicate oxygen analyses were checked within 0.04 per cent. except in one or two cases. The greatest variation allowable between duplicates is 0.06 per cent.

A description of the calculation is given very clearly by Boothby and Sandif̣ord. ${ }^{12}$ We have used a slightly different set of tables for correction of gas volumes. They may be found in convenient form by Wells. ${ }^{13}$

\section{DISCUSSION OF RESULTS}

Experimental data are given in Table 1 . Ten subjects were used, five of whom were normal. The most striking thing on first inspection of this table is the difference between tuberculous and normal individuals in volume expired per unit of time. The explanation of this is quite obviously to be found in the reduced vital capacity of the tuberculous patients. Peabody ${ }^{14}$ has shown that normal individuals may increase

9. Devised by Dr. Donald Van Slyke of the Rockefeller Institute for Medical Research.

10. We are indebted to Dr. Wm. C. Stadie for this point in technic.

11. Henderson, Y.: The Haldane Gas Analyser, J. Biol. Chem. 33:31, 1918.

12. Boothby, W. M., and Sandiford, I.: Basal Metabolic Rate Determinations, 1920, W. B. Saunders Company, Philadelphia.

13. Wells, H. L.: Tables for Chemical Calculations, 1903, Henry Holt, New York, p. 10.

14. Peabody, F.: Cardiac Dyspnea, A. J. M. Sc. 155:100, 1918. 
the tidal air up to one third of the vital capacity, beyond which point further increase in respiratory exchange must be accomplished by increasing the rate of respiration. Since the dead space has a relatively constant volume, increasing the rate of respiration decreases the ratio of effective minute volume to total minute volume expired. This results in a lower percentage of carbon dioxid and a higher percentage of oxygen in expired air, other factors being equal.

Referring to Table 2 it will be seen that for each of the five normals and five patients the minute volume and tidal air have been tabulated from the data for each basal period. For the normals the average minute volume was 4.25 liters, average respirations were 11 per minute and average tidal air $397 \mathrm{c}$. c. This is 11 per cent. of the average normal vital capacity as estimated from the surface area by the formula of

TABLE 2.-Minute Volume and Tidal Air

\begin{tabular}{|c|c|c|c|c|c|c|c|c|}
\hline Name & $\begin{array}{c}\text { Volume } \\
\text { Expired, } \\
\text { Basal } \\
\text { Liters } \\
\text { per Hr. }\end{array}$ & $\begin{array}{c}\text { Resp. } \\
\text { per } \\
\text { Min. }\end{array}$ & $\begin{array}{l}\text { Minute } \\
\text { Volume, } \\
\text { C.c } \\
\text { Expired }\end{array}$ & $\begin{array}{c}\text { Tidal } \\
\text { Air, } \\
\text { C.c. }\end{array}$ & $\begin{array}{c}\text { Effective } \\
\text { Minute } \\
\text { Volume, } \\
\text { C.c. }{ }^{*}\end{array}$ & $\begin{array}{c}\mathrm{CO}_{2} \\
\text { C.c.per } \\
\text { Min. } \\
\text { Pro- } \\
\text { duced }\end{array}$ & $\begin{array}{c}\text { Ratio of } \\
\text { Total } \\
\text { Min. Vol. } \\
\text { to CO2 } \\
\text { per Min. }\end{array}$ & $\begin{array}{l}\text { Ratio of } \\
\text { Fffective } \\
\text { Min. Vol. } \\
\text { to COz } \\
\text { per Min. }\end{array}$ \\
\hline 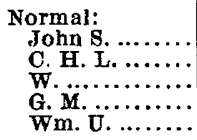 & $\begin{array}{l}274.6 \\
266.2 \\
304.2 \\
203.8 \\
227.6\end{array}$ & $\begin{array}{r}16 \\
12 \\
12 \\
7 \\
9\end{array}$ & $\begin{array}{l}4,577 \\
4,437 \\
5,070 \\
3,397 \\
3,793\end{array}$ & $\begin{array}{l}286 \\
370 \\
423 \\
485 \\
421\end{array}$ & $\begin{array}{l}2,497 \\
2,877 \\
3,510 \\
2,487 \\
2,623\end{array}$ & $\begin{array}{l}185 \\
185 \\
214 \\
132 \\
121\end{array}$ & $\begin{array}{l}24.7 \\
23.9 \\
23.7 \\
25.7 \\
31.3\end{array}$ & $\begin{array}{l}13.5 \\
\cdot 15.5 \\
16.4 \\
18.9 \\
21.6\end{array}$ \\
\hline Average...... & $\ldots$ & 11 & 4,255 & 397 & 2,799 & 167 & 25.9 & 17.2 \\
\hline $\begin{array}{r}\text { Tuberculous:.... } \\
\text { Ab. M. .......... } \\
\text { Fred R. ........ } \\
\text { J. O'C. ....... } \\
\text { Geo. R. ........ } \\
\text { J. V. B. ....... }\end{array}$ & $\begin{array}{l}578.5 \\
540.5 \\
434.0 \\
434.2 \\
487.7\end{array}$ & $\begin{array}{l}36 \\
30 \\
24 \\
16 \\
19\end{array}$ & $\begin{array}{l}9,641 \\
9,008 \\
7,233 \\
7,237 \\
8,128\end{array}$ & $\begin{array}{l}268 \\
300 \\
301 \\
452 \\
428\end{array}$ & $\begin{array}{l}4,961 \\
5,108 \\
4,113 \\
5,158 \\
5,658\end{array}$ & $\begin{array}{l}208 \\
192 \\
173 \\
193 \\
206\end{array}$ & $\begin{array}{l}46.3 \\
46.9 \\
41.8 \\
37.5 \\
39.5\end{array}$ & $\begin{array}{l}23.8 \\
26.6 \\
23.8 \\
26.7 \\
27.5\end{array}$ \\
\hline Average...... & $\ldots$. & 25 & 8,249 & 350 & 4,799 & 195 & 42.5 & 25.7 \\
\hline
\end{tabular}

* Effective minute volume $=$ total minute volume minus respirations per minute $\times 130$ c.c. The average dead space assumed to be 130 e.c.

West. ${ }^{15}$ In the tuberculous series the average minute volume was 8.25 liters, average respiration rate 25 per minute and average tidal air 350 c. c. The value for the tidal air must be approximately maximal inasmuch as in all of the tuberculous cases increases in metabolism were accompanied by accelerated respirations. If the same ratio of maximal tidal air to vital capacity obtains in tuberculosis as in normals this would indicate an average vital capacity of from 1,000 to 1,100 c. c. This figure is undoubtedly lower than these subjects would have shown if the vital capacity were determined in the erect posture. It probably represents the reduced vital capacity of the recumbent posture.

15. West, H. F.: A Comparison of Various Normal Standards for the Normal Vital Capacity of the Lungs, Arch. Int. Med. 25:306 (March) 1920. 
In Table 2 the effective minute volume, or alveolar ventilation for each individual has been calculated on the assumption that the dead space was 130 c. c. This gives an average effective alveolar ventilation for the five normals of 2,799 c. c., and for the five patients of 4,799 c.c. However, it will be seen that the average amount of carbon dioxid eliminated per minute was higher in the tuberculous series, 195 c.c. per minute for the patients against 167 c.c. per minute for the normals. The ratio of total ventilation to volume carbon dioxid eliminated is almost twice as large for the tuberculous cases as for the normals. Even when they are compared on the basis of the ratio of effective alveolar ventilation to carbon dioxid elimination the ratio is again less for the normals: 17.2 for normals and 25.7 for patients. This is in keeping with the results of experiments on the effect of artificially elevating body temperature. Hill and Flack ${ }^{16}$ called attention to the overventilation which occurs in subjects immersed in hot boths. A marked fall in alveolar carbon dioxid tension was noted. Haggard ${ }^{17}$ has shown that under these circumstance there is a diminution of the ratio $\left(\mathrm{H}_{2} \mathrm{CO}_{3}: \mathrm{NaHCO}_{3}\right)$, which he believed to be due to the decreased solubility of carbon dioxid at elevated body temperatures. He found that the alveolar carbon dioxid tension was reduced, and that the carbon dioxid combining power of the blood was not correspondingly changed.

It should be pointed out, however, that, in the basal observations which are tabulated in Table 2, the elevation of temperature was in no case very high, so that there may be other unknown factors which enter into the production of the overventilation of these patients.

In Table 3 are tabulated the comparisons of the percentage increases in heat production and total pulmonary ventilation after the ingestion of varying amounts of foodstuffs. It will be seen at once that the parallelism is very close in both normal and tuberculous subjects.

In considering the effect of protein ingestion it will be seen that there is considerable variation in the amount of increase of heat production. There are several factors which determine the extent to which protein will increase heat production: First, the amount of protein relative to the size of the individual subject; second, the previous nutritive condition of the subject or the level of endogenous protein metabolism at the time of ingestion of protein food. Environmental temperature plays a part. The development of our knowledge of these

16. Hill, L., and Flack, M.: The Influence of Hot Baths on Pulse Frequency, Blood Pressure, Body Temperature, Breathing Volume and Alveolar Tension of Man, J. Physiol, 38:57, Proc., 1909,

17. Haggard, H. W.: The Alteration of the Carbon Dioxid Ratio $\left(\mathrm{H}_{2} \mathrm{CO}_{34}\right.$ : $\mathrm{NaHCO}_{3}$ ) in the Blood During Elevation of Body Temperature J. Biol. Chem. 44:131, 1920. 
factors is the result of the researches of Rubner ${ }^{1}$ and Lusk. ${ }^{2}$ The amounts of protein ingested have been expressed in terms of grams per square meter of body surface area. In the cases of C. H. L. and $\mathrm{J} . \mathrm{O}^{\prime} \mathrm{C}$. the amount of protein ingested was not sufficient to increase the heat production; it served merely to replace endogenous protein.

External temperature probably plays no part in these experiments since all subjects had sufficient covering to maintain perfect comfort. This gives an evironmental temperature of about $33 \mathrm{C}$. at the skin surface. The effect of previous nutritive condition is very strikingly shown in the case of William U., who ingested protein after sixteen days of complete starvation. Subject John S. habitually lives on a very low protein diet. Subject $W$. lives on a high protein diet. His nitrogen excretion per hour before ingesting protein was higher than that observed subsequently. Tuberculous subjects Fred R. and Geo. R. behaved similarly to the four subjects studied by McCann and Barr ${ }^{3}$ in the respiration calorimeter.

TABle 3.-Percentage Increase in Heat Production and Pulmonary Ventilation After Eating

\begin{tabular}{|c|c|c|c|c|c|c|c|}
\hline Name & $\begin{array}{l}\text { Amount } \\
\text { Foodstuff } \\
\text { Ingested, } \\
\text { Gm. }\end{array}$ & $\begin{array}{c}\text { Calories } \\
\text { per Hr. } \\
\text { Basal }\end{array}$ & $\begin{array}{c}\text { Maximum } \\
\text { Calories } \\
\text { per Hr. } \\
\text { after } \\
\text { Food } \\
\text { Ingestion }\end{array}$ & $\begin{array}{c}\text { Increase } \\
\text { Heat } \\
\text { Pro- } \\
\text { duced, } \\
\text { per Cent. }\end{array}$ & $\begin{array}{c}\text { Increase } \\
\text { Ventila- } \\
\text { tion, } \\
\text { per } \\
\text { Cent. }\end{array}$ & $\begin{array}{c}\text { Time of } \\
\text { Maximum } \\
\text { Increase } \\
\text { Hrs. after } \\
\begin{array}{c}\text { Inges- } \\
\text { tion }\end{array}\end{array}$ & $\begin{array}{c}\text { Grams } \\
\text { Protein } \\
\text { per } \\
\text { Sq. Meter } \\
\text { Body } \\
\text { Surface }\end{array}$ \\
\hline 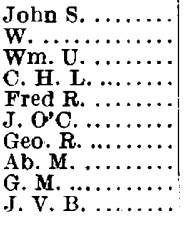 & $\begin{array}{r}73 \text { protein } \\
96 \text { protein } \\
105 \text { protein } \\
31 \text { protein } \\
61 \text { protein } \\
21 \text { protein } \\
73 \text { protein } \\
140 \text { fat } \\
100 \text { glucose } \\
100 \text { glucose }\end{array}$ & $\begin{array}{l}60.4 \\
75.0 \\
46.5 \\
59.7 \\
75.0 \\
62.0 \\
67.6 \\
72.7 \\
53.1 \\
74.9\end{array}$ & $\begin{array}{l}84.6 \\
84.0 \\
67.0 \\
61.6 \\
91.6 \\
55.3 \\
87.0 \\
82.1 \\
57.7 \\
74.3\end{array}$ & $\begin{array}{c}40 \\
12 \\
44 \\
3 \\
22 \\
(-11) \\
29 \\
12 \\
12 \\
0\end{array}$ & $\begin{array}{l}40 \\
11 \\
32 \\
20 \\
20 \\
\left(\begin{array}{c}55 \\
25\end{array}\right. \\
14.5 \\
32 \\
17\end{array}$ & $\begin{array}{l}2 \\
21 / 2 \\
31 / 2 \\
51 / 2 \\
31 / 2 \\
21 / 2 \\
3 \\
21 / 3 \\
11 / 2 \\
1-11 / 2\end{array}$ & $\begin{array}{l}43 \\
50 \\
64 \\
20 \\
40 \\
13 \\
45\end{array}$ \\
\hline
\end{tabular}

That protein has a specific dynamic action in tuberculosis brings this disease into sharp contrast with typhoid fever. In the latter disease the endogenous protein metabolism is already high at the time of ingesting protein, which merely replaces endogeous protein. ${ }^{18}$ McCann and Barr $^{3}$ have shown that the level of protein metabolism in tuberculosis is not high, so that ingestion of protein increases the total oxidative processes.

Lusk, ${ }^{2}$ quoting Rubner, states that when 100 per cent. of the basal requirement of energy is ingested as meat there is, an average increase

18. Coleman, W., and DuBois, E. F.: Calorimetric Observations on the Metabolism of Typhoid Patients With and Without Food, Arch. Int. Med. 15:2 (Jan.) 887 (June) 1915. 
of 36.7 per cent. in the twenty-four hour heat production, if ingested as fat, the metabolism is raised 12.7 per cent. and if as sugar, 5.8 per cent.

Murlin and Lusk ${ }^{19}$ and Magnus Levy ${ }^{20}$ find somewhat lower figures for the specific dynamic action of fat than those of Rubner. For each 100 calories of ingested fat the metabolism is increased: Rubner, 12.7 calories; Murlin and Lusk, 4.1 calories; and Magnus Levy, 2.5 calories.

In the case of Abr. M., ingestion of 1,312 calories as fat increased the heat production 12 per cent. in from two to five hours. The ingestion of only 410 calories as glucose in the case of J. V. B. caused no increase in metabolism but increased the ventilation 17 per cent., and in the case of G. M. the metabolism rose 12 per cent. and the ventilation rate 32 per cent. Thus, it is seen that the greatest number of calories may be ingested in the form of fat with the least effect on the total ventilation. A marked increase in ventilation occurs during carbohydrate oxidation in spite of a small specific dynamic action. This is due to the relatively greater quantities of carbon dioxid to be eliminated, or, in other words, to the higher respiratory quotient of carbohydrate metabolism. Confirmatory evidence on this point has been found in the work of Benedict and Carpenter. ${ }^{21}$ These authors studied the effect of the ingestion of many foods on the heat production and gaseous exchange. Unfortunately, in the experiments on fat and protein no data are given regarding the ventilation. However, some of their carbohydrate experiments were made with the Tissot spirometer. They found (p. 231) that the average maximum effects were produced, in the order of greatest to least, by sucrose, levulose, lactose, and dextrose. On page 217, Table 149, subject H. H. A., after ingestion of $100 \mathrm{gm}$. sucrose the ventilation increased from 4.29 liters per minute to a maximum of 6.86 liters per minute, an increase of 2.57 liters, or 60 per cent. The carbondioxid elimination increased 55 per cent., while the oxygen consumption rose only 14 per cent.

\section{ADDENDA}

Description of Experimental Subjects.-It should be emphasized that all of the tuberculous subjects were in an advanced stage of the disease. With the exception of J. V. B., a detailed history will be found for each in a subsequent communication, "The Protein Requirement in Tuberculosis."

19. Murlin, J. R., arid Lusk, G.: J. Biol. Chem. 22:15, 1915.

20. Magnus, L. A.: Arch. f. d. ges. Physiol. 55:1, 1894.

21. Benedict, F. G., and Carpenter, T. M.: Food Ingestion and Energy Transformations, Carnegie Institution of Washington, D. C., Pub. No. 261, pp. 217, 231. 
CASE 1.-Ab. M., an Arabian male, aged 21 years, height $168 \mathrm{~cm}$., weight 40 $\mathrm{kg}$. Acute illness of two months' duration with signs of pneumonic consolation of the entire left lung. Many tubercle bacilli in the sputum. Temperature range, from 100 to $104 \mathrm{~F}$.

CASE 2.-Fred R., aged 41 years, height $167 \mathrm{~cm}$., weight $47 \mathrm{~kg}$. History of chronic cough and loss of weight for three years' duration. Had been hospitalized for eight months. Many tubercle bacilli in the sputum. Marked emaciation, dyspnea and cyanosis. Physical signs of extensive bilateral infiltration with numerous cavities. Confirmation by roentgenogram and necropsy.

CASE 3.-J. O'C., a male, aged 49 years, height $174.3 \mathrm{~cm}$., weight $49.7 \mathrm{~kg}$. History of probable active pulmonary tuberculosis of eleven years' duration. Chronic cough, slow emaciation, and slight hemoptyses. Symptoms became acute and urgent only one month before admission. Physical signs of infiltration of both upper lobes of lungs, more advanced on the right side, with small amount of fluid in the right pleura. Some enlargement of the heart with retraction of the heart to the right. Many tubercle bacilli in the sputum. Temperature range from 97.4 to $102.2 \mathrm{~F}$.

CASE 4.-George R., aged 35 years, height $163.5 \mathrm{~cm}$., weight $57 \mathrm{~kg}$. History of fistula in ano for three years. Pulmonary symptoms of six months duration. Marked constitutional symptoms of only two months' duration-night sweats and loss of weight. Physical and fluoroscopic examination showed marked infiltration of both upper lobes with a large cavity in each. Sputum contained many tubercle bacilli. Temperature range from 98 to $101 \mathrm{~F}$.

CASE 5.-J. V. B., a male, aged 43 , height $174 \mathrm{~cm}$., weight $44.4 \mathrm{~kg}$. Symptoms all developed within six months-cough, night sweats, and a loss of weight of 42 pounds. Fluoroscopic examination showed a large cavity in the left upper lobe, below which there was consolidation with multiple excavations. The right middle and upper lobes were densely infiltrated, containing multiple excavations. There was a similar condition in the apex of the right lower lobe. Sputum contained many tubercle bacilli. Temperature range from 98 to $102 \mathrm{~F}$.

The normals used as controls are described briefly as follows:

CASE 6.- John S., laboratory assistant, aged 21 years, height $165 \mathrm{~cm}$., weight $61.5 \mathrm{~kg}$. Subject was fat. Had no symptoms of serious nature during two years in the laboratory. Physical examination and urine examination revealed no abnormalities.

CASE 7.-C. H. L., a female medical student aged 26 years, height $161.1 \mathrm{~cm}$., weight $539 \mathrm{~kg}$. Had been in good health during three years of medical course. Physical examination negative. Urine normal.

CASE 8.-W., a male medical student, height $179 \mathrm{~cm}$., weight $73 \mathrm{~kg}$. Large athletic individual in perfect health. Physical examination negative. Urine normal.

CAs' 9.-G. M., physician, female, aged 32 years, height $160 \mathrm{~cm}$., weight $56.05 \mathrm{~kg}$. In perfect health. Physical examination normal. Urine normal.

CASE 10.-Wm. U., a lawyer, aged 42 years, height $179 \mathrm{~cm}$., weight $51.7 \mathrm{~kg}$. Had an abscess in neck in childhood; gonorrhea in 1902; mastoiditis and chronic otitis media from 1914 to 1916; malaria of the quartan type in 1509; in perfect health during experiment. He had undertaken a fasting experiment, which he had done several times before. Between Nov. 28, 1920, and the date of the respiration experiment of Jan. 19,1921, he had fasted forty-two days in three periods of 10,16 and 16 days respectively. The experiment given in Table 1 is the breaking of the last sixteen day fast. The meal taken was one of pot cheese which had been washed thoroughly until it was practically free from 
carbohydrates. The physical examination was normal, except for emaciation due to fasting. He was 71 pounds under the weight at the start of fasting, November 28. Urine normal.

\section{CONCLUSIONS}

1. The total pulmonary ventilation of five cases of advanced pulmonary tuberculosis was approximately twice that of five normal controls. The percentage of carbon dioxid produced and of oxygen absorbed, in terms of expired air, was much reduced as compared with normals.

2. The alveolar ventilation in the tuberculous patients was greater than that of the normal subjects, as was the ratio of alveolar ventilation to the volume of carbon dioxid expired.

3. The ingestion of protein food increased both heat production and total pulmonary ventilation in a corresponding degree in both tuberculous patients and controls. After ingestion of $70 \mathrm{gm}$. protein (from 40 to $45 \mathrm{gm}$. per square meter of body surface) heat production was increased from 22 to 29 per cent. and ventilation from 20 to 25 per cent. in tuberculous subjects.

4. In the form of fat the greatest number of calories may be ingested with the least effect on the pulmonary ventilation. Carbohydrates increase the ventilation out of all proportion to their effects upon the general oxidative processes and heat production. This is believed to be due to the relatively greater quantities of carbon dioxid eliminated during carbohydrate oxidation, in other words, to the higher respiratory quotient. 